\title{
GENDER DALAM KEHIDUPAN MASYARAKAT SASAK: KAJIAN DEIKSIS GENDER DALAM BAHASA SASAK
}

\author{
Syamsinas Jafar ${ }^{1}$, M. Nasaruddin M. Ali ${ }^{2}$, Mahmudi Efendi ${ }^{3}$, \\ Muh. Khairussibyan ${ }^{4}$, I Nyoman Sudika ${ }^{5}$, Kaharuddin ${ }^{6}$, Sapiin $^{7}$ \\ Universitas Mataram \\ e-mail: syamsinas_jafar@unram.ac.id
}

\begin{abstract}
The Sasak people recognize the concept of gender deixis in the sociocultural context of daily life. In daily interactions, the Sasak people need gender deixis in the context of kinship life, traditional life such as traditional rituals, and matters related to their livelihoods. The purpose of this study is to describe the form and meaning of gender deixis in the Sasak language in the sociocultural context of the life of the Sasak people in the context of their traditional traditions and livelihoods. The theory used in this research is the theory of McConnell-Ginet (1987) which reveals that in the lingual elements of language there is a realization of a gender perspective which shows and is embedded in the elements of selfconcept, perception and outlook on life of men and women. This study uses a qualitative method with structured and unstructured participatory observation techniques, in-depth interviews with informants. The results of this study indicate that in the context of the socio-cultural life of the community, especially in traditional rituals and livelihoods, it is full of gender deixis which is realized in its lingual forms. Meaningfully, the lingual forms of gender deixis in the Sasak language refer to the sociocultural concepts and perspectives of men and women in Sasak society which reflect on the principles of kinship and respect, responsibility, deliberation and consensus and romanticism, strength and refinement.
\end{abstract}

Keywords: deixis, gender deixis, sociocultural context

\section{PENDAHULUAN}

Bahasa merupakan realiasasi dari konteks sosial-budaya masyarakat pemakainya. Salah satu konteks sosialbudaya yang terealisasi melalui bahasa adalah konteks gender. Konteks gender dalam bahasa dapat berhubungan dengan sistem kedeiksisan. Sistem kedeiksisan yang berkaitan dengan kajian ini adalah deiksis gender. Konteks deiksis gender berkaitan dengan kajian deiksis sosial.

Sebagai fenomena sosial-budaya, bahasa Sasak memiliki karakteristik khas dalam merealisasikan fenomena tentang gender. Fenomena gender ini misalnya terlihat pada satuan lingual gender yang selalu berkolokasi dengan nama diri seseorang. Penanda lingual gender $l o$ 'lakilaki' dan le 'perempuan' digunakan untuk menandai sapaan nama diri seperti dalam lo Amin (sapaan nama diri laki-laki) dan le Siti ( (sapaan nama diri perempuan). Sapaan lain yang merealisasikan gender adalah bentuk pronomina persona. Dalam bahasa Sasak, sapaan gender terlihat pada pemakaian sapaan pronomina persona kedua, seperti me 'kamu' untuk laki-laki dan $b i$ 'kamu' untuk perempuan. Dalam masyarakat Sasak lainnya, seperti di wilayah Suralaga Lombok Timur, khususnya di kalangan bangsawan dikenal pula sapaan gender yang melekat pada nama diri, yaitu Naq untuk perempuan dan $P e$ untuk laki-laki (Mahyuni, dkk, 2016). Sebagai fenomena gender, dua bentuk ini dapat dipahami sebagai sapaan antara lakilaki dan perempuan yang berimplikasi pada nilai dan sikap saling toleransi serta menghargai, yang senantiasa dijaga dan dipelihara antara pria dan wanita.

Fenemena gender seperti ini dapat pula ditemukan pada bahasa lain, seperti pada bahasa Bima (lihat Intiana dkk, 2006). Bahasa Bima misalnya memiliki dua bentuk jerder amania ' saudara laki-laki' dan amancawa 'saudara perempuan' untuk kerabat sekandung. Dalam implikasi pemakaiannya sapaan ini kemudian ditujukan kepada kerabat, tidak hanya saudara sekandung melainkan juga siapa 
saja yang dianggap sebagai kerabat. Demikian pula dalam bahasa Sumbawa, dalam bentuk sanaksawai dan sanaksalaki yang masing-masing dapat diartikan sebagai sapaan 'saudara perempuan' dan 'saudara laki-laki' (lihat Jafar dkk, 2007). Kedua sapaan bahasa Bima dan Sumbawa ini dapat disamakan dengan sapaan bahasa Inggris brother 'saudara laki-laki' dan sister 'saudara perempuan' yang secara sosial-kultural, berbeda pemaknaan gendernya baik dalam bahasa Bima, bahasa Sumbawa maupun bahasa Sasak.

Deiksis gender dalam bahasa Sasak diduga tidak hanya ditemukan dalam bentuk sapaan nama diri dan pronomina persona tetapi dapat mencakup bentuk lingual pada sistem lainnya, seperti halnya yang telah ditemukan pada bahasa Bima dan bahasa Sumbawa (lihat Intiana dan Jafar, 2006; Jafar dan Intiana, 2007) dalam pemakaian berbagai konteks seperti dalam konteks sistem tradisi adat, ritual keagamaan. dan mata pencaharian.

Fenomena gender seperti ini, merupakan bagian dari kajian deiksis gender yang digagas oleh McConnell (1987). Kajian deiksis gender adalah salah satu kajian dalam sistem bahasa yang mencoba menemukan ciri dan makna yang bersifat inheren dan alamiah yang dapat merealisasikan perspektif gender yang ditunjukkan dan ditandai oleh bentukbentuk lingual bahasa (bandingkan Sapir, 1929, Hans 1944 dalam MeConneIl-Ginet, 1987:80). Artinya, kajian deiksis gender merupakan fenomena kebahasaan yang akan melahirkan unsur-unsur lingual bahasa yang didalamnya menunjuk atau melekat unsur-unsur nilai- sosial dan budaya komunitas masyarakat, dalam kaitannya dengan konsep diri, persepsi, pandangan hidup wanita-pria.

Deiksis gender dalam bahasa Sasak diduga tidak hanya ditemukan dalam bentuk nama diri dan pronomina persona tetapi dapat mencakup bentuk leksem pada sistem lainnya, seperti pemaakaiannya dalam konteks sistem tradisi adat, ritual keagamaan. dan mata pencaharian.
Penelitian deiksis jeuder dalam bahasa Sasak juga akan dibatasi pada tataran leksern, terutarna bentuk-bentuk lingual yang dipakai dalam konteks sistern kekerabatan, tradisi adat, dan ritual agama, dan mata pencaharian. Ke empat aspek ini merupakan bagian dari nilai sosial-budaya yang diharapkan bersentuhan langsung dengan realisasi dari perspektif gender.

Deiksis gender dalam bahasa Sasak menarik untuk ditelusuri, karena belum pernah diteliti. Adanya penelitian deiksis gender bahasa Sasak ini diharapkan dapat mengisi khasanah penelitian di bidang sosiolinguistik/etnolinguistik.

Kajian deiksis gender dalam bahasa Sasak ini akan dibatasi pada tataran leksem, terutama leksem-leksem yang dipakai dalam konteks sistem kekerabatan, tradisi adat, ritual agama, dan mata pencaharian. Selain itu akan dibahas pula makna leksem-leksem deiksis gender bahasa Sasak yang terealisasi dalam konteks sistem kekerabatan, tradisi adat, mata pencaharian.

Secara umum, kajian bahasa dan gender sebenarnya telah banyak dilakukan. Beberapa di antaranya Lakoff (1975) (dalam McConnel-Ginet, 1987). Deborah Tannen (1985) (dalam Scollon 1995:229), Uyeno (1971), Gumperz (1992) (dalam Duranti, 1997), Dale Spender (1994). Kajian tentang deiksis dalam bahasa juga bukan ha] yang baru. Telah banyak penelitian tentang deiksis yang dilakukan para linguius antara lain Fillmore (1966) Lyons ([977), Brecht (1974) Ebeling (1978) Kaswanti (1981). Kaswanti (1984) secara detail telah pula menelaah deiksis bahasa Indonesia. Adapun pengkajian tentang deiksis gender secara imptisit dilakukan oleb Levinson (I985) dalam gagasannya tentang konsep deiksis sosial. Gagasan ini yang mengilhami konsep deiksis gender yang dikemukakan McConnel-Ginet (1987).

Dalam bahasa, deiksis berasal dari bahasa Yunani deiktos yang berarti 'hal penunjukkan secara langsung'. Menurut Ebeling (1978) (dalam Kaswanti, 1984), 
deiksis diartikan sebagai menunjuk pada luar luturan yang berpusat pada orientasi pembicara. Hal penunjukkan luar tuturan ini disebut Fillmore (dalam Kaswanti, 1984: 9) sebagai titik labuh ( setting anchorage). Kimball (1974) (dalam Kaswanti, 1984: 39) mengatakan bahwa orientasi pembicara memiliki ciri orientasi bawaan/inheren ( inherent orientation). Konsep deiksis yang digagas. McConnelGinet. ( 1987) secara teoritis dapat ditafsirkan sebagai pemahaman seperti ini (deiksis dipahami pula sebagai bagian kajian dalam tuturan, berorientasi tempelan (induced orientation), dan titik tolak (text anchorage). Artinya, menurut McConnell-Ginet (1987: 85-86) deiksis gender berusaha menemukan bentukbentuk bahasa yang tidak hanya menunjuk perbedaan 'feminin atau 'maskulin', tapi lebih pada adanya fakta 'penyesuaian' yang secara deiktis menentukan tipe kelas sebagai identifikasi gender. Selain itu yang lebih krusial menurutnya adalah dalam realisasi pemakaiannya (language use), deiksis gender akan merefleksikan tentang konsep diri, persepsi, pandangan hidup yang berlatar social-budaya sebagai bagian yang inheren dari perspektif gender.

Deiksis gender dapat dipertentangkan dengan apa yang disebnt McConnet-Ginet (1987) 'genderlect', yaitu fenomena kebahasaan dalam perspektif gender yang di dalarnnya tidak menunjuk atau menandai sifat alamiah dan inheren. Dalan 'genderlect ini dapat ditemukan fenomena stereotipe gender (gender stereotypes), norma gender (gender norms) atau penanda gender (gender markers). Bahasa-bahasa yang hanya memiliki ciri pembagian jenis kelamin tidak dapat disebut sebagai berciri deiksis gender tetapi disebut sebagai bahasa yang berciri penanda gender. Demikian pula bahasa yang dikaji hanya berorientasi politis (isu gender) menurut McConnell -Ginet adalah upaya rekayasa dalam bahasa yang disebutnya sebagai streotipe gender.
McConnell-Ginet (1987) mencatat beberapa bahasa yang menunjukkan adanya fenornena deiksis gender. Dalam bahasa Kurux Dravida misalnya (berdasarkan penelitian Ekka (1974) terdapat penanda 'feminin' dalam leksem kategori verba konjungsi yang memperlihatkan hanya digunakan oleh sesama wanita. Dalam kajian ini sebenarnya tidak teraktualisasi tentang bagaimanakah konteks pemakaiannya sehingga tergambar tentang kedeiktisan gender dalam mengungkapkan perspektif jerder. Demikian pula halnya contoh deiksis gender yang dipaparkan pada bahasa Koasati - Amerindian dari hasil penelitian Haas (1944). Dalam bahasa ini tidak dijelaskan apakah adanya perbedaan pemakaian fonologis pada lakilaki dengan penambahan bunyi /s/ pada tiap akhir leksem verba, dengan wanita yang tidak menggunakannya berimplikasi pada makna-makua yang bernilai pada perspektif gender. Perbedaan pengunaan secara fonologis hanya menjelaskan adanya pembeda penanda lingual pada wanita-pria.

Dalam bahasa lain, seperti bahasa Jepang (periksa Holmes, 1992: 166) deiksi gender ditemukan dalam bentuk leksem pronomina saya. Wanita menggunakan bentuk atashi, sedangkan boku dipakai oleh laki-laki. Bentuk netralnya adalah watakushi yang dapat dipakai oleh laki-laki dan wanita. Dalam tataran kalimat, wanita mengakhiri kalimat dengan partikel ne ( periksa Wardaugh, 1990: 304) sedangkan laki-laki menggunakan partikel wa (Uyeno, 1971 dalam Duranti. 1997:211). Penelitian bahasa Jepang ini juga tidak terperinci menjelaskan realisasi perspektif gender. Hal ini karena tidak tergambar suatu uraian tentang implikasi pemakaiannya yang dapat mengungkapkan tentang persepsi, sudut pandang yang berlatar sosial-budaya (yang dapat dimaknai sebagai bagian dari titik labuh / unsur luar tuturan) dari wanita-pria (dapat dimaknai sebagai orientasi bawaan).

Dalam bahasa Dryrbal (periksa Wardaugh, 1990: 306) terungkap adanya pemakaian variasi yang jelas antara wanita dan pria, namun dapat terjadi hanya satu 
variasi yang digunakan karena adanya syarat tabu. Untuk memenehi syarat tabu, hanya lazim digunakan satu variasi bahasa, yaitu variasi bahasa wanita. Tampaknya bahasa Dryrbal dan bahasa-bahasa lainnya yang setipe ini, lebih jelas menggambarkan makna berperspektif gender. Dalam bahasa Dryrbal ini dapat dipahami bahwa secara sosial-budaya, pemilihan variasi bahasa wanita menunjukkan bahwa setidaknya wanita, dipandang memiliki kekuatan untuk tidak ditabukan (dihargai). Holmes (1992: 165-166) mengatakan fenomena kebahasaan yang deiktis seperti ini dapat disebut sebagai bahasa kelompok 'ekslusif'. Bahasa kelompok 'eksklusik' ini menurutnya terdapat pada suku Amazon, yang hanya mensyaratkan pemasyarakatan bahasa dan garis laki-laki. Artinya pada suku Amazon hanya digunakan bahasa suami oleh istri, bahasa ayah (tidak bahasa ibu -yang harus berlainan suku dengan ayah) oleh anak. Bahasa ini oleh Hudson (1995:1 20) sebagai bahasa 'patrilingual'. Secara maknawi dalam bahasa ini. menunjukkan bahwa pria lebih dihargai oleh masyarakat Amazon.

Fenomena yang lebih spesifik sebagai kelompok bahasa 'ekslusif', ditunjukkan Holmes pada bahasa Yana, Amerika Utara yang secara rapi memiliki sistem leksem nomina untuk laki-laki dan wanita, seperti antara lain, untuk menyebut orang digunakan yaa oleh wanita, yaa-na oleh laki-laki. Demikian pula masingmasing dipakai $b a$ dan ba-na untuk menyebut rusa. Bahasa 'ekslusif' seperti bahasa Yana ini dapat ditafsirkan sebagai bahasa yang berciri deiktis. Namun seperti telaah lainnya, kajian-kajian ini belum menelaah lebih tajam dan mendalam tentang bentuk-bentuk deiksis gender. Dalam kajian-kajian ini belum ditemukan pemaknaannya dalam konteks pemakaiannya yang lebih luas, sehingga dapat teungkap lebih jelas makna sosialbudaya yang berperspektif gender dalam bahasa-bahasa tersebut.

Hasil penelitian bahasa Bima tentang deiksis gender, menunjukkan bahwa ditemukan bentuk-bentuk deksis gender dalam berbagai konteks, seperti dalam konteks sistem kekerabatan, tradisi adat, ritual keagamaan dan sistem mata pencaharian. Dalam konteks-konteks tersebut selain ditemukan bentuk deiksis yang hanya membagi jenis kelamin, terdapat bentuk-bentuk netral yang pemakaiannya mencerminkan konsepsi diri masyarakatnya yang sarat dengan sikap toleransi, penghargaan dan penghormatan antara pria dan wanita. Namun sebagai cerminan budaya lokal, bentuk-bentuk deiksis gender dalam bahasa Bima tetap menunjukkan pengungkapan tentang persepsi gender bahwa partisipasi wanita bersifat material dan logistik, sedangkan pria ada pada wilayah yang bersifat pemikiran. Hal ini misalnya tercermin pada bentuk deiksis gender pada konteks tradisi adat. Terdapat aktivitas yang disebut teka ra nee. Secara harafiah istilah ini diartikan kegiatan 'turun naik dari rumah panggung' di tempat yang sedang berhajat yang dilakukan oleh wanita. Kegiatan ini berlangsung berhari-hari untuk tujuan memberi sumbangan berupa material (uang atau bahan makanan) dan tenaga bagi yang berhajat. Sebagai kontrasnya, terdapat istilah mbolo, yang artinya 'berkumpul membentuk bundaran'. Dalam perspektif gender aktivitas mbolo dapat dipahami lakilaki berkumpul untuk berpatsipasi bermusyawarah dalam hal sumbang gagasan dan pikiran.

\section{METODE PENELITIAN}

Sumber data dalam penelitian ini diperoleh dari sumber berupa informan, responden, wacana bahasa Sasak. Para infoman adalah penutur asli bahasa Sasak yang akan memberikan informasi tentang bahasa Sasak, yang berkaitan dengan datadata tentang bentuk dan makna deiksis gender. Responden merupakan para inforrnan yang akan memberikan data tentang bentuk bahasa Sasak. Melalui daftar tanyaan atau kusioner sebagai instrumen penelitian ini. Para responden (dan informan) diambil dari enam 
kecamatan yang dipilih sebagai sampel penelitian. Wacana bahasa Sasak adalah sumber data yang diperoleh melalui observasi partisipan, berupa hasil rekaman percakapan sehari-hari, yang bersifat umum (data tidak berstruktur) dan khusus ( data berstruktur). Wacana bahasa Sasak juga akan diperoleh melalui wawancara mendalam (Brannen, 1997).

Pengumpulan data dalam penelilian ini menggunakan metode kualitatif. Dalam metode kualitatif ini, pengumpulan data dilakukan melalui cara membagikan kusioner, observasi partisipan, wawancara mendalam. Kusioner adalah daftar tanyaan yang akan dipakai untuk menjaring data tentang bentuk deiksis gender bahasa Sasak. Kusioner akan disebarkan kepada 120 orang reponden, yang dipilih masingmasing 30 orang pada masing-masing tiga Kabupaten Lombok Barat, Lombok Tengah, Lombok Timur dan Kodya Mataram, sebagai sampel penelitian. Responden (yang juga informan) dipilih sesuai dengan syarat/kriteria sebagai informan/respondon, antara lain berpendidikan minimal Sekolah Dasar, berusia 16 sd 70 tahun, menguasai bahasa Sasak dengan baik, lahir dan tinggal dalam jangka waktu lama. di daerah Lombok (bandingkan Samarin 1988).

Observasi partisipan akan

dilakukan dengan dua cara, yaitu observasi berstruktur dan tak berstruktur (bandingkan Labov, 1974). Observasi berstruktur adalah merekam tuturan bahasa Sasak dari para informan, melalui pemberian topik tertentu. Observasi tidak berstruktur adalah merekam tuturan bahasa Sasak di tempattempat umum seperti pasar, terminal, tempat hiburan. Dua cara ini digunakan untuk menjaring pemakaian deiksis gender, sehingga diketahui bentuk dan makna dalam pemakainnya. Wawancara mendalam adalah cara yang dipihh untuk lebih mempertajam pemahaman tentang makna deiksis gender, terutama untuk mengetahui aspek-aspek sosial-budaya yang inheren memaknai perspektif gender.
Analisis data dilakukan melalui tahap-tahap berikut.

1. Mendeskripsikan bentuk deikis gender bahasa Sasak, dari data kusioner dan observasi partisipan. Bentuk deiksis gender di deskripsikan terdiri dari leksemleksem dalam konteks sistem kekerabatan, tradisi adat, ritual keagamaan, mata pencaharian.

2. Menganalisis makna deiksis gender bahasa Sasak, melalui data observasi partisipan dan wawancara mendalam. Makna deiksis gender dianalisis terdiri atas makna deiksis gender yang terdapat dalam leksem sistem kekerabatan, tradisi adat, ritual keagamaan, mata pencaharian.

\section{HASIL DAN PEMBAHASAN \\ Bentuk Deiksis Gender dalam Bahasa Sasak}

Bentuk deiksis gender dalam bahasa Sasak dapat ditemukan dalam konteks sistem kekerabatan, tradisi adat, ritual keagamaan dan mata pencaharian. Dalam kajian ini bentuk deiksis gender akan diuraikan dalam tataran leksem yang di dalamnya mengandung makna kedeiksisan gender. Bentuk deiksis gender dalam konteks-konteks tersebut diuraikan berikut ini.

\section{Bentuk Deiksis Gender dalam Konteks Sistem Kekerabatan}

Bentuk-bentuk deiksis gender bahasa Sasak dalam konteks sistem kekerabatan yang ditemukan meliputi hirarki kehidupan kekerabatan gender dari bayi sampai dewasa. Hal ini dapat dilihat dalam bentuk-bentuk kekerabatan sebagai berikut.

1) Gede-Ciq

Bentuk sapaan ini adalah sebutan kekerabatan untuk bayi yang belum diberi nama. Sapaan gede sebutan untuk bayi laki-laki, sedangkan sapaan ciq sebutan untuk bayi perempuan.

2) Nune-Dende 
Sapaan ini adalah sapaan untuk memanggil anak-anak, laki-laki dan anak perempuan dalam keluarga. Sapaan nune 'anak lakilaki' untuk anak laki-laki dan dende 'anak perempuan'. Sapaan ini juga dapat digunakan pada anak-anak, laki-laki dan perempuan di luar kerabat.

3) Terune-Dedare

Bentuk terune 'laki-laki (muda)' dan dedare 'perempuan (muda)' merupakan dua leksem sapaan kekerabatan yang digunakan untuk laki-laki dan perempuan dalam keluarga yang dianggap telah remaja atau dewasa. Dalam bahasa Indonesia sapaan ini dapat disamakan dengan perjaka dan gadis. Sapaan ini secara umum dapat pula dipakai untuk sapaan kepada laki-laki dan perempuan.

4) Loq-Le

Dua bentuk sapaan ini dipakai untuk menyebut jenis kelamin lakilaki dan perempuan yang biasanya diikuti sapaan nama diri. Sapaan log dan le dapat disamakan dengan si dalam bahasa Indonesia. Bentuk log dipakai untuk laki-laki seperti terlihat dalam bentuk loq Amin dan le untuk perempuan seperti dalam le Sarah.

5) Semeton mame-semeton nine Seperti halnya bahasa Bima dan Sumbawa, bahasa Sasak memiliki dua leksem gender sapaan kekerabatan yaitu sapaan, yaitu semeton mame 'saudara laki-laki' dan semeton nine 'saudara perempuan'. Dua sapaan ini merupakan sapaan yang dapat bersifat spesifik (khusus) dan generik (umum). Secara spesifik dua leksem ini dipakai untuk sapaan saudara kandung laki-laki dan perempuan. Secara generik kedua sapaan ini dapat pula dipakai untuk laki-laki dan perempuan yang bukan saudara kandung.
6) Meq- $\mathrm{Bi}$

Bentuk ini hampir sama dengan bentuk loq-le yaitu bentuk sebutan gender jenis kelamin tapi lebih dipakai untuk kepemilikan. Bentuk ini juga selalu menyertai nama diri, seperti meq Salim untuk laki-laki, bi Ani untuk sapaan perempuan.

7) Amaq rari- inaq rari

Bentuk sapaan ini merupakan sapaan kekerabatan yang ditujukan pada adik kandung orang tua. Amaq rari 'paman' adalah sapaan untuk adik kandung laki-laki dari orang tua. Inaq rari 'bibi' sapaan untuk adik kandung perempuan dari orang tua. Namun sapaan ini juga dapat ditujukan pada laki-laki dan perempuan dewasa yang berkerabat atau di luar kerabat.

8) Mamiq

Sapaan ini merupakan sapaan untuk orang tua laki-laki yang sama dengan bapak dalam bahasa Indonesia. Sapaan mamiq biasanya dipakai sebagai sapaan kekerabatan untuk kalangan bangsawan. Namun dalam pemakaiannya bentuk ini dapat dipakai pada laki-laki dewasa pada umumnya sebagai bentuk sapaan penghormatan.

\section{Bentuk Deiksis Gender dalam Konteks Sistem Tradisi Adat}

Dalam bahasa Sasak bentuk deiksis gender banyak ditemukan dalam tradisi perkawinan. Bentuk deiksis gender dalam tradisi perkawinan lebih menggambarkan peran fungsi laki-laki dari pada perempuan, karena prosesi pernikahan lebih ditentukan oleh laki-laki. Berikut ini uraian beberapa bentuk deiksis gender dalam konteks tradisi adat perkawinan.

Dalam bahasa Sasak dikenal beberapa bentuk istilah tradisi perkawinan yang diperankan laki-laki seperti berikut ini. 
9) Midang

Bentuk midang 'mengunjungi' adalah kegiatan awal seorang lakilaki ke rumah perempuan untuk menyatakan simpati, senang, cinta dan sekaligus memperkenalkan diri pada keluarga perempuan.

10) Nanggep

Bentuk nanggep hampir sama dengan midang, yaitu kegiatan lakilaki mendatangi rumah perempuan untuk tujuan menyatakan keinginan simpati dan suka kepada pihak perempuan.

11) Merarik

Merarik 'membawa lari' adalah pihak laki-laki membawa (lari) perempuan untuk maksud dinikahi.

12) Sejati

Bentuk sejati adalah kegiatan kunjungan pihak laki-laki ke rumah orang tua perempuan untuk memberitahukan bahwa anak perempuannya telah diambil untuk dinikahi.

13) Ngelamar

Ngalamar adalah kunjungan lakilaki ke rumah perempuan untuk tujuan meminang.

14) Selabar

Selabar adalah kunjungan penghulu (dari pihak laki-laki) kepada pihak perempuan menemui wali perempuan untuk meminta izin menikah.

15) Nyongkol

Nyongkol adalah kegiatan pihak laki-laki setelah prosesi sejati, ngelamar dan selabar dilakukan. Nyongkol adalah kegiatan kunjungan laki-laki ke pihak keluarga perempuan untuk tujuan silaturahmi dan mempererat hubungan.

16) Sorong Serah

Kegiatan sorong serah adalah kegiatan pihak laki-laki menyerahkan aji krame (mahar) kepada pihak perempuan sebagai biaya perhelatan nikah.

17) Ijab qabul

Kegiatan terakhir prosesi pernikahan adalah ijab qabul, yaitu ikrar pernikahan secara agama yang disaksikan penghulu dan wali nikah. Kegiatan ini umumnya dilakukan di rumah pihak laki-laki karena konsekuensi telah melakukan merarik.

\section{Bentuk Deiksis Gender dalam Konteks Mata Pencaharian}

Bentuk deiksis gender bahasa Sasak yang ditemukan dalam konteks mata pencaharian antara lain dalam konteks kehidupan bertani/petani dan melaut/nelayan. Bentuk-bentuk deiksis gender dalam konteks mata pencaharian ini tercermin melalui pembagian kerja laki-laki dan perempuan.

\section{Bentuk Deiksis Gender dalam Konteks Bertani}

Beberapa bentuk deiksis gender dalam konteks bertani berdasarkan peran laki-laki adalah sebagai berikut.

18) Ngaro

Ngaro 'membajak' adalah kegiatan laki-laki mengolah tanah yang akan ditanami padi dengan menggunakan sapi atau alat membajak.

19) Nambah Pengamparan

Nambah pengamparan 'mencangkul' adalah kegiatan lakilaki mengolah tanah sawah dengan alat cangkul untuk menebar benih.

20) Ngampar

Ngampar 'menyebar benih' adalah bagian kegiatan laki-laki menyebar benih padi sebelum menanam padi.

21) Ngengilis

Ngengilis 'mengairi' adalah kegiatan laki-laki membuat saluran air di pinggir tanaman, seperti padi, tembakau, ubi.

22) Ruruh Aiq

Ruruh aiq adalah kegiatan laki-laki mengalirkan air ke sawah. 
23) Roros Reban

Roros reban adalah kegiatan lakilaki memperlancar saluran air sawah.

24) Ngegambis

Ngegambis adalah kegiatan lakilaki membersihkan rumput dengan alat (arit) pada pematang sawah.

25) Berambas Berambas adalah kegiatan laki-laki membersihkan semak belukar.

26) Memundukin

Memundukin adalah kegiatan lakilaki menambal pematang dengan lumpur sawah.

27) Meleng bineq

Meleng bineq adalah kegiatan lakilaki memotong benih padi.

28) Nungkep

Nungkep adalah kegiatan laki-laki menumpuk/menyusun padi yang sudah dipanen.

29) Lembah Kenjeu

Lembah kenjeu adalah kegiatan laki-laki memikul padi yang sudah dipotong tangkainya.

30) Nyedut Roman

Nyedut roman adalah kegiatan lakilaki membakar jerami setelah sawah dipanen.

31) Ngerek-rek

Ngerek-rek adalah kegiatan lakilaki membuka/membuat sawah baru.

32) Nyenyisip

Nyenyisip adalah kegiatan laki-laki menambah atau mengganti tanaman baru setelah padi dipanen.

33) Bobonto

Bobonto adalah kegiatan laki-laki membuat orang-orangan sawah.

34) Beraboq

Beraboq adalah kegiatan laki-laki memupuk tanaman/padi yang baru ditanam.

35) Mbang-mbang
Mbang-mbang adalah kegiatan lakilaki membuat jalan air di tengah sawah.

\section{6) Tembuku}

Tembuku adalah kegiatan laki-laki membuat pembatas pada parit/saluran air dengan kayu atau bambu.

Beberapa sebutan dalam konteks bertani berdasarkan peran perempuan adalah sebagai berikut.

37) Memanoang

Memanoang adalah kegiatan perempuan mengantarkan makanan dan minuman ke sawah.

38) Reas

Reas adalah kegiatan perempuan mencabut benih padi.

39) Lowong

Lowong adalah kegiatan perempuan menanam padi.

40) Ngome

Ngome adalah kegiatan perempuan membersihkan rumput liar di sekitar tanaman padi dengan menggunakan alat.

41) Mataq

Mataq adalah kegiatan perempuan memotong tangkai padi agar menjadi pendek.

42) Nuliq

Nuliq adalah kegiatan perempuan mengikat padi yang telah dipotong tangkainya menjadi pendek.

43) Begetuq

Begetuq adalah kegiatan perempuan memanen padi dengan menggunakan alat (ani-ani).

44) Muro

Muro adalah kegiatan perempuan mengusir burung dan mengawasi dan menjaga padi yang akan dipanen.

45) Nepiq

Nepiq adalah kegiatan perempuan membersihkan kotoran beras/gabah dengan nyiru.

46) Ngendang 
Ngendang adalah kegiatan perempuan menjemur padi atau gabah.

\section{Bentuk Deiksis Gender dalam Konteks Melaut/Nelayan}

Bentuk deiksis gender dalam Konteks melaut atau pekerjan sebagai nelayan terbagi dalam dua kategori berdasarkan peran-fungsi laki-laki dan perempuan.

Beberapa sebutan untuk laki-laki dalam kegiatan melaut adalah sebagai berikut.

47) Mencar

Mencar adalah kegiatan menangkap ikan dengan menggunakan jarring yang dilempar.

48) Gegadon

Gegadon adalah kegiatan menangkap ikan pada sore hari.

49) Memadaq

Memadaq adalah kegiatan menangkap ikan pada saat air laut surut.

50) Memanaq

Memanaq adalah kegiatan menangkap ikan dengan menggunakan panah.

51) Panje

Panje adalah kegiatan menangkap ikan di tengah laut (melaut).

52) Ngerakat

Ngerakat adalah kegiatan menangkap ikan dengan menggunakan jaring besar.

53) Ngujur

Ngujur adalah kegiatan menarik perahu yang datang dari tengah laut membawa hasil tangkapan ikan menuju pinggir pantai.

54) Ngarampo

Ngarampo adalah kegiatan menangkap ikan di malam hari dengan menggunakan jaringan dan perahu.

55) Tabi-Tabi

$\begin{array}{lrr}\text { Tabi-tabi } & \text { adalah } & \text { kegiatan } \\ \text { menangkap } & \text { ikan } & \text { dengan }\end{array}$

menggunakan tempurung pada saat air surut.

56) Pemelas

Pemelas adalah kegiatan menangkap ikan di tengah laut yang agak jauh.

57) Bebedil

Bebedil adalah kegiatan menangkap ikan dengan menggunakan senapan.

58) Bejaring Leq Sedi

Bejaring leq sedi adalah kegiatan menangkap ikan dengan jarring dari pinggir pantai.

Sebutan kegiatan melaut untuk perempuan tidak banyak ditemukan. Berikut ini bentuk deiksis gender dalam kegiatan membantu nelayan pria yang diperankan perempuan.

59) Pengayum

Pengayum adalah tugas perempuan yaitu menjahit jarring yang rusak pada saat digunakan melaut.

60) Mindang

Mindang adalah kegiatan mematangkan ikan dengan cara dikukus untuk dijual di pasar.

61) Njual Empak

Njual empak adalah kegiatan menjual ikan hasil melaut di pasar.

\section{Makna Deiksis Gender dalam Bahasa Sasak}

Uraian berikut ini mengungkapkan makna deiksis gender dalam bahasa Sasak yang terefleksi dalam bentuk, sebutan dalam konteks sistem kekerabatan, tradisi adat, dan mata pencaharian.

Makna Deiksis Gender dalam

Konteks Sistem Kekerabatan.

(1) Merefleksikan Konsep Diri Kekerabatan antara Laki-Laki dan Perempuan

Refleksi tentang konsep diri kekerabatan antara laki-laki dan perempuan 
tampak pada pemakaian bentuk semeton mame 'saudara laki-laki' dan semeton nine 'saudara perempuan' (lihat contoh (5)). Kedua sebutan kekerabatan ini tidak hanya dipakai untuk saudara sekandung tapi juga dipakai sebagai sapaan kepada laki-laki dan perempuan di luar saudara kandung, kerabat dan yang bukan kerabat. Fungsi pemakaiannya yang generik tersebut menunjukkan bahwa dikembangkan asas kekerabatan kepada laki-laki dan perempuan mana saja yang dianggap sebagai kerabat.

Demikian pula hal yang sama terlihat pada fungsi penggunaan sapaan amaq rarik 'paman' - inaq rarik 'bibi' (lihat contoh (7) dan mamiq 'ayah' (contoh (8).

\section{(2) Merefleksikan Konsep Diri tentang Penghormatan antara Laki-Laki dan Perempuan \\ Konsep diri tentang penghormatan} kepada laki-laki dan perempuan terungkap pada sapaan kekerabatan seperti loq-le (contoh (4)) dan meq-bi (contoh (6). Dua sebutan ini dipakai secara spesifik untuk sapaan masing-masing kepada lakilaki dan perempuan dewasa sebagai penghormatan terhadap gender.

\section{(3) Merefleksikan Konsep Diri tentang Keakraban terhadap Laki-Laki dan Perempuan \\ Konsep keakraban terhadap laki-} laki dan perempuan tampak terefleksi melalui sapaan dalam kerabat mulai dari bayi sampai remaja. Hal ini terlihat pada penggunaan sapaan untuk bayi laki-laki dan perempuan, gede-ciq (contoh (1), anakanak nune-dende (contoh (2), remaja, terune-dedare (contoh (3).

\section{Makna Deiksis Gender dalam Konteks Tradisi Adat \\ (1) Merefleksikan Sikap Tanggung Jawab \\ Refleksi tanggung jawab dalam} konteks tradisi adat adalah tanggung jawab laki-laki terhadap perempuan. Hal ini terlihat pada prosesi adat perkawinan seperti pada kegiatan sejati (contoh (12)), ngelamar, (contoh 13), selabar (contoh 14), ijab qabul (conoh (17) sebagai konsekuensi tindakan merarik 'melarikan (perempuan)' yang telah dilakukan lakilaki.

(2) Merefleksikan Musyawarah
Mufakat
Asas musyawarah mufakat terefleksi melalui tindakan soroh serah (contoh (16)). Sorong-serah sebagai langkah selanjudnya dalam prosesi sebelum pernikahan yang di dalamnya berisi acara ritual menyerahkan aji krame (mahar) oleh pihak laki-laki, mengimplimentasikan telah dilakukannya musyawarah mufakat pada kedua pihak laki-laki dan perempuan.

(3) Merefleksikan

Kekeluargaan

Refleksi sikap kekeluargaan tercermin melalui tindakan dalam nyongkol. Prosesi nyongkol adalah acara kunjungan pihak laki-laki dan keluarganya ke pihak perempuan dan keluarganya untuk saling mengenal lebih dekat dan menjalin silaturahmi.

(4) Merefleksikan Kasih Sayang dan Romantisme

Romantisme dan kasih sayang antara laki-laki dan perempuan terlihat dalam tindakan yang disebut midang (contoh (1)), nanggep (contoh (2), merarik (contoh (3)). Ketiga kegiatan yang dilakukan oleh laki-laki ini merupakan perwujudan adanya kasih sayang dan romantisme yang terjalin antara laki-laki dan perempuan yang bersifat alamiah.

\section{Makna Deiksis Gender dalam Konteks Mata Pencaharian.}

(1) Merefleksikan tentang Kekuatan dan Kehalusan

Refleksi kekuatan tampak pada istilah-istilah kegiatan yang dilakukan lakilaki baik pada kegiatan bertani maupun melaut. Dalam aktivitas bertani dan melaut yang dilakukan laki-laki terefleksi kekuatan 
yang mengandung makna yang bersifat fisik dan maskulin.

Dalam kegiatan bertani kekuatan tercermin dalam tindakan antara lain, ngaro 'membajak' (contoh (18)), merambas 'membabat semak belukar' (contoh (25)), lembah kenjeu 'memikul (padi)' (contoh (29)), ngerek-rek 'membuat sawah/lahan baru' (contoh (31)). Dalam kegiatan melaut refleksi kekuatan tercermin dalam tindakan antara lain panje (contoh (51)), ngrampo (contoh (54)), dan pemelas (contoh (55)). Ketiga kegiatan ini memerlukan fisik terberat karena melakukan menangkap ikan di tengah laut pada malam hari dan dilakukan berhari-hari dengan perahu.

Refleksi kehalusan tampak pada aktivitas bertani dan melaut yang dilakukan perempuan. Refleksi kehalusan tercermin pada jenis pekerjaan perempuan yang tidak terlalu membutuhkan kekuatan fisik tapi lebih bersifat ringan/feminim. Hal ini tampak misalnya pada kegiatan bertani seperti reas 'mencabut benih padi' (contoh (38)), lowong 'menanam padi' (contoh (39)), begetuq 'memanen padi' (contoh (43)), muro 'mengusir burung di tengah sawah' (contoh (44)).

Refleksi kehalusan juga tampak tergambar pada kegiatan bertani dan melaut oleh para perempuan yang bersifat domestik. Hal ini seperti tampak pada kegiatan bertani memanoang 'mengantar makanan minuman ke sawah' (contoh (37)), nepiq 'membersihkan gabah/padi' (contoh (45)), ngendang 'menjemur padi' (contoh (46)). Dalam kegiatan melaut ruang domestic terlihat pada tindakan mindang 'mengolah ikan' (contoh (58)), mengayum 'menjahit jaring/jala' (contoh (57)), njual empak 'menjual ikan' (contoh (59)).

\section{KESIMPULAN}

1. Dalam bahasa Sasak terdapat bentuk-bentuk deiksis gender dalam konteks sistem kekerabatan, tradisi adat (perkawinan), dan konteks mata pencaharian (bertani dan melaut).
2. Bentuk-bentuk deiksis gender dalam bahasa Sasak tersebut mengacu pada deiksis gender lakilaki, perempuan.

3. Makna deiksis gender bahasa Sasak merefleksikan diri tentang gender yang terkait dengan konsep kekuatan dan kehalusan yang tampak pada konteks mata pencaharian. Kekuatan terefleksi pada kegiatan jenis pekerjaan lakilaki, kehalusan terefleksi pada kegiatan jenis pekerjaan perempuan.

4. Makna deiksis gender bahasa Sasak juga merefleksikan tentang asas kekerabatan, penghormatan/penghargaan, keakraban yang tercermin pada istilah-istilah gender dalam konteks sistem kekerabatan.

5. Makna deiksis gender bahasa Sasak merefleksikan tentang konsep tentang sikap tanggung jawab, musyawarah mufakat dan romantisme dan kasih sayang yang termanifestasi dalam istilah-istilah gender dalam konteks tradisi adat.

\section{SARAN}

1. Hasil penelitian deiksis gender bahasa Sasak ini diharapkan dapat menjadi bahan yang komprehensif bagi penelitian deiksis gender pada bahasa lain.

2. Hasil penelitian ini diharapkan pula dapat menjadi sumbangan yang memadai bagi penelitian di bidang sosiolinguistik/etnolinguistik.

3. Kajian ini diharapkan dapat dilanjutkan untuk kajian yang lebih mendalam tentang deiksis gender dalam konteks kehidupan berbudaya masyarakat Sasak, terutama dalam konteks ritual keagamaan yang belum ditemukan dalam penelitian ini.

\section{DAFTAR PUSTAKA}


Brown, Julia 1997. Memadu Metode Penelitian Kualitatif. Yogyakarta: Pustaka Pelajar.

Duranti, Alessandro. 1997. Linguistic Anthropology. Melbourne Cambridge University Press.

Ginet and Mc. Connell. 1988. Language the Sociocultural Contexs. Volume IV. Melbourne: Cawbridge University Press.

Hudson, R. A (Terj. Rochayah). 1995. Sosiolinguistik. Jakarta: Pusat Pembinaan dan Pengembangan Bahasa.

Holmes, Janet. 1992. An Introduction to Sociolinguistisc. New York: Longman.

Kaswanti, Bambang Purwo. 1984. Deiksis dalam Bahasa Indonesia. Jakarta: PN Balai Pustaka.
Levinson, Stephen. C. 1985. Pragmatics. Melbourne Sidney: Cambridge University Press.

Labov, William. 1990. "The Reflection of Social Processes in Linguistics Strucrures". Dalam Joshua Fishman (ed). Reading in the Sociology of Language.

Samarin, William. 1970. (terj. J.S Badudu). 1988. Ilmu Bahasa Lapangan. Yogyakarta: Penerbit Kanisius.

Spender. Dale. 1994. Man Made Language. London: Pandore Press.

Scollon, Ron. dlkk. 1995. Intercultural Communication. Black Well. Oxford UK and Cambridge USA. Wardaugh, Roland. 1990, An Introduction to Sociolinguistics. Cambridge: Basic Blackwell. 